\author{
Marcin Żurawski \\ Uniwersytet Mikołaja Kopernika, Toruń \\ zurawski@doktorant.umk.pl
}

\title{
Pozytywne i negatywne przesłanki ogłoszenia upadłości konsumenckiej
}

DOI: http://dx.doi.org/10.12775/SIT.2017.019

\section{Uwagi wprowadzające}

Instytucja upadłości konsumenckiej została wprowadzona do polskiego systemu prawnego po uchwaleniu Ustawy $z$ dnia 5 grudnia 2008 r. o zmianie ustawy - Prawo upadłościowe i naprawcze oraz ustawy o kosztach sądowych w sprawach cywilnych ${ }^{1}$. Regulacja ta miała na celu wprowadzenie nowego rozwiązania - możliwości ogłoszenia upadłości, a w konsekwencji oddłużenia osób fizycznych nieprowadzących działalności gospodarczej.

Konieczność wprowadzenia takich regulacji jest efektem zmian w Unii Europejskiej, które miały miejsce na przełomie lat 70. i 80. Początkowo nieopłacalne (duży wkład własny, ograniczony okres kredytowania) kredyty i pożyczki dla gospodarstw domowych stały się łatwiej dostępne na skutek deregulacji sektora consumer finance, co zaowocowało wzrostem zadłużenia społeczeństwa. Banki, wcześniej specjalizujące się w udzielaniu kredytów przedsiębiorcom, dostrzegły możliwość osiągania zysku w oferowaniu kredytów dla konsumentów. Szczególnie intensywnie promowane w tamtym okresie były karty kredytowe. Konsumenci finansowali

\footnotetext{
${ }^{1}$ Dz.U. z 2008 r. Nr 234, poz. 1572.
} 
z uzyskanych środków przede wszystkim bieżącą konsumpcję, nie posiadając jednocześnie dostatecznej wiedzy na temat warunków podpisywanych umów kredytowych. Kryzys ekonomiczny początku lat 90. w Unii Europejskiej doprowadził do sytuacji, w której nie tylko najbiedniejsi mieli problem $z$ regulowaniem swoich zobowiązań, ale także gospodarstwa domowe zaliczane do klasy średniej napotkały trudności ze spłatą hipoteki oraz innych rodzajów kredytów i pożyczek².

Wśród przyczyn powstawania zjawiska wzrostu zadłużenia społeczeństwa (powstawania zjawiska „życia na kredyt”) wskazuje się dwa główne źródła. Po pierwsze, problem polega na stale zwiększanej podaży ofert usług finansowych - kredytów bankowych, sprzedaży na raty, pożyczek udzielanych przez inne niż bank instytucje finansowe, a także możliwości korzystania $z$ kart kredytowych. Po drugie, przyczyną takiej sytuacji jest zjawisko typowe dla każdej zdrowej gospodarki - rosnący, realny popyt na tego typu usługi. $Z$ czasem zadłużenie gospodarstw domowych nieprowadzących działalności gospodarczej może okazać się tak wysokie, że dłużnicy nie są w stanie spłacać go $z$ uzyskiwanych bieżących dowodów. Wśród przyczyn tego zjawiska można wymienić przykładowo utratę zdrowia uniemożliwiającą kontynuowanie pracy zarobkowej, utratę pracy, przecenianie swoich możliwości finansowych. Niewypłacalność osób fizycznych rodzi konsekwencje nie tylko dla dłużnika, ale również jego rodziny czy kontrahentów. Powstawanie takich sytuacji doprowadziło do wprowadzania w niektórych systemach prawnych rozwiązań, które polegają na uregulowaniu na nowo relacji $z$ wierzycielami, prowadzące do częściowego lub całkowitego oddłużenia osób, które nie prowadzą działalności gospodarczej - jest to tzw. upadłość konsumencka ${ }^{3}$.

Regulacja dotycząca upadłości konsumenckiej nie została objęta obowiązkiem harmonizacji przez prawodawcę unijnego, a co za tym idzie, każde z państw członkowskich Unii Europejskiej ma w tym

2 A. Szymańska, Upadłość konsumencka $w$ Polsce na tle doświadczeń innych krajów Unii Europejskiej, Warszawa 2014, s. 92-93.

${ }^{3}$ W. Szpringer, Upadłość konsumencka. Inspiracje z rozwiazań światowych oraz rekomendacje dla Polski, Warszawa 2006, s. 16-17. 
zakresie swobodę co do metody i sposobu regulacji. Prowadzi to do znaczących różnic pomiędzy poszczególnymi rozwiązaniami prawnymi w tym zakresie ${ }^{4}$.

Przedmiotem niniejszego artykułu są przesłanki ogłoszenia upadłości konsumenckiej - modelowe rozwiązania stosowane w ustawodawstwach innych państw, rozwiązania stosowane w polskim prawie w latach 2009-2014 oraz od 31 grudnia 2014 r. po wejściu w życie Ustawy z dnia 29 sierpnia 2014 r. o zmianie ustawy - Prawo upadłościowe i naprawcze, ustawy o Krajowym Rejestrze Sądowym oraz ustawy o kosztach sądowych w sprawach cywilnych ${ }^{5}$, która doprowadziła do gruntownej reformy instytucji upadłości konsumenckiej.

\section{Przesłanki ogłoszenia upadłości konsumenckiej w systemach prawnych wybranych państw Unii Europejskiej}

Istnieją różne modele regulacji upadłości konsumenckiej co do dostępu do tej instytucji. Można wskazać modele oparte na: dostępie powszechnym, dostępie tylko przy niewielkim zadłużeniu, dostępie przy znaczącym zadłużeniu, ograniczeniu do pewnych rodzajów długów, a nawet możliwości łączenia długu konsumenta z długami tej samej osoby jako prowadzącej niewielką działalność gospodarczą. Istnieje jednak zgoda, że możliwość upadłości konsumenckiej powinna być przewidziana dla konsumenta uczciwego, lecz skrzywdzonego przez $\operatorname{los}^{6}$.

W 2013 r. regulacje dotyczące upadłości konsumenckiej istniały w 24 z 28 państw członkowskich Unii Europejskiej, a w pozostałych (w Bułgarii, Chorwacji, Rumunii oraz na Węgrzech) trwały prace nad ich wprowadzeniem. Pierwszym krajem, który wprowadził do swojego systemu prawnego omawianą instytucję, była Dania - miało

${ }^{4}$ R. Adamus, A.J. Witosz, A. Witosz, Upadłość konsumencka. Komentarz praktyczny, Warszawa 2009, s. 9.

5 Dz.U. z 2014 r. Poz. 1306.

${ }^{6}$ W. Szpringer, op.cit., s. 23. 
to miejsce w 1984 r. W systemie prawnym tego kraju konsument musi udowodnić, że jest nadmiernie zadłużony i nie będzie w stanie spłacić swoich zobowiązań w ciągu następnych lat. Podobne rozwiązania zastosowano w Szwecji ${ }^{7}$.

We Francji upadłość konsumencka może zostać orzeczona w stosunku do osoby fizycznej, która nie posiada zaległości w świadczeniach publicznoprawnych i działa w dobrej wierze. Ponadto musi wystąpić przesłanka wyraźnej niemożności spłacenia długów. Upadłość może zostać orzeczona tylko i wyłącznie na wniosek dłużnika ${ }^{8}$.

W Niemczech początkowo procedurą były objęte osoby fizyczne, które nie wykonywały samodzielnej działalności gospodarczej w większym rozmiarze, później poszerzono ten krąg o drobnych przedsiębiorców i osoby samodzielnie wykonujące zawód. Procedura przeznaczona dla osób fizycznych - konsumentów obejmuje te $z$ nich, przeciwko którym nie ma roszczeń ze stosunku pracy, pod warunkiem że liczba wierzycieli nie przekracza 20. Dla postępowania nie jest istotna sytuacja majątkowa danej osoby - może obejmować także osoby zamożne (np. udziałowców czy akcjonariuszy spółek). Przesłanką wszczęcia procedury jest przedłożenie przez konsumenta zaświadczenia o bezskutecznej próbie ułożenia się $z$ wierzycielem, która prowadzona była przed specjalną komisją. Prawo do wszczęcia postępowania ma zarówno wierzyciel, jak i dłużnik ${ }^{9}$.

W Holandii osoby ubiegające się o ogłoszenie upadłości powinny załączyć do wniosku sądowego tzw. certyfikat dobrej woli, wydawany przez miejskiego mediatora. Zawarte w nim są informacje dotyczące sytuacji dłużnika. Do obligatoryjnych negatywnych przesłanek ogłoszenia upadłości należy taka sytuacja finansowa wnioskodawcy, która świadczy o tym, że nie będzie on w stanie spłacić swoich długów, a upadłość może mu posłużyć do wykorzystania wierzycieli. Do fakultatywnych negatywnych przesłanek należy okoliczność, że dłużnik w okresie 10 lat poprzedzających złożenie wniosku zaciągnął jeden lub więcej kredytów niezgodnie $z$ „dobrą wolą” ${ }^{10}$.

\footnotetext{
7 A. Szymańska, op.cit., s. 94-100.

8 W. Szpringer, op.cit., s. 29.

9 Ibidem, s. 35-36.

10 A. Szymańska, op.cit., s. 101.
} 
Prawo fińskie przewiduje listę sytuacji, w których dłużnik nie może uzyskać dostępu do procedury upadłości konsumenckiej, takich jak działalność przestępcza lub podejrzenie o taką działalność, inne czynności dokonywane przeciwko interesom wierzycieli, nieujawnienie lub podanie nieprawdziwych informacji w czasie postępowań egzekucyjnych, niezgodne $z$ prawdą oświadczenia składane w celu uzyskania kredytu oraz uzasadnione podstawy do przypuszczenia, że nie będzie realizował planu spłaty, a także okoliczność, że dłużnik doprowadził do trudnej sytuacji na skutek nieodpowiedzialnego działania ${ }^{11}$.

Podsumowując, przesłanki ogłoszenia upadłości konsumenckiej w państwach członkowskich Unii Europejskiej są sformułowane w sposób zróżnicowany. W państwach, w których położono nacisk na pozasądowy etap postępowania upadłościowego, wymagane są dokumenty, które poświadczają niepowodzenie negocjacji z wierzycielami. Do najczęściej występujących negatywnych przesłanek należy zaliczyć złą wolę dłużnika oraz działanie na szkodę wierzycieli.

\section{Przesłanki ogłoszenia upadłości w polskim systemie prawnym w latach 2009-2014}

Ustawa $z$ dnia 8 grudnia 2008 r. obejmowała zakresem upadłości konsumenckiej jedynie osoby, wobec których nie prowadzono postępowania upadłościowego przewidzianego dla przedsiębiorców. Regulacja ta nie obejmowała osób fizycznych, które były przedsiębiorcami i zostały wykreślone $z$ właściwego rejestru (w ciągu roku od dnia wykreślenia), a także osób fizycznych faktycznie prowadzących działalność gospodarczą, także wówczas, gdy nie dopełniła obowiązku zgłoszenia tej działalności we właściwym rejestrze. Mimo iż z formalnego punktu widzenia te osoby były osobami fizycznymi

11 U. Reifner, J. Kiesilainen, N. Huls, H. Springeneer, Consumer Overindebtness and Consumer Law in European Union, Final Report, s. 182, http://www. ecri.eu/new/system/files/26+consumer_overindebtedness_consumer_law_ eu.pdf (dostęp: 26.02.2017 r.). 
nieprowadzącymi działalności gospodarczej, stosowana wobec nich była procedura upadłościowa przewidziana dla przedsiębiorców ${ }^{12}$.

Zgodnie $\mathrm{z}$ art. $491^{2}$ ust. 2 ustawy z dnia 28 lutego 2003 r. Prawo upadłościowe i naprawcze ${ }^{13}$ (dalej: pun) wniosek o ogłoszenie upadłości konsumenckiej mógł zgłosić tylko dłużnik. Podstawową przesłanką ogłoszenia upadłości była niewypłacalność dłużnika, rozumiana według art. 11 ust. 1 pun - tzn. dłużnika uważa się za niewypłacalnego, jeżeli nie wykonuje swoich wymagalnych zobowiązań pieniężnych. Dodatkową przesłanką ogłoszenia upadłości, wynikającą $z$ przepisu art. $491^{3}$ ust. 1 pun, była okoliczność, że niewypłacalność dłużnika powstała wskutek wyjątkowych i niezależnych od niego okoliczności. W przeciwnym razie sąd był obowiązany do oddalenia wniosku o ogłoszenie upadłości, w szczególności w przypadku, gdy dłużnik zaciągnął zobowiązanie, będąc niewypłacalnym, albo do rozwiązania stosunku pracy dłużnika doszło z przyczyn leżących po stronie pracownika lub za jego zgodą. Za wyjątkowe w rozumieniu ustawy uważano okoliczności spowodowane obiektywnymi okolicznościami, nie tylko dotyczące stosunków gospodarczych (np. dekoniunktura na rynku pracy, zmiany w zakresie kursu walut), ale również osoby dłużnika (takie jak choroba, niepełnosprawność). Natomiast za niezależne od dłużnika okoliczności uznawano nie tylko brak elementu winy tej osoby fizycznej, ale również w pewnych sytuacjach brak wiedzy o zaistniałych okolicznościach, do której posiadania nie był on obowiązany ${ }^{14}$.

$Z$ uwagi na brak wyłączeń w tym zakresie, mając na względzie utrwalone orzecznictwo Sądu Najwyższego w zakresie upadłości przedsiębiorców, należało przyjąć, że do ogłoszenia upadłości konsumenckiej konieczne było posiadanie przynajmniej dwóch wierzycieli. Rozwiązanie to było nieadekwatne do celów ustawy, gdyż uniemożliwiało skorzystanie $z$ procedury oddłużeniowej osobie fizycznej tylko dlatego, że zaciągnęła jeden dług, który doprowadził do niewypłacalności ${ }^{15}$.

12 R. Adamus, A.J. Witosz, A. Witosz, op.cit., s. 25.

13 Tekst jednolity: Dz.U. z 2009 r. Nr 175, poz. 1361.

14 R. Adamus, A.J. Witosz, A. Witosz, op.cit., s. 62-63.

15 E. Kabza, Wybrane problemy upadtości konsumenckiej $w$ świetle nowej 
Dla zastosowania negatywnej przesłanki ogłoszenia upadłości, dotyczącej zaciągnięcia zobowiązania przez dłużnika będącego w stanie niewypłacalności, co do zasady nie miał znaczenia fakt pozytywnej weryfikacji zdolności kredytowej dłużnika przez bank. Weryfikacja ta nie oznaczała jednocześnie automatycznej dyskwalifikacji tej negatywnej przesłanki, konieczne było badanie sprawy poprzez pryzmat jej konkretnych okoliczności ${ }^{16}$.

Artykuł $491^{3}$ ust. 2 pun przewidywał katalog negatywnych przesłanek ogłoszenia upadłości. I tak sąd miał obowiązek oddalić wniosek o ogłoszenie upadłości w czterech przypadkach, które musiały mieć miejsce w okresie 10 lat przed złożeniem wniosku o ogłoszenie upadłości. Pierwsza taka sytuacja zachodziła jeżeli w stosunku do dłużnika prowadzono postępowanie upadłościowe lub inne postępowanie, w którym umorzono całość lub część jego zobowiązań albo w którym zawarto układ. Kolejną przesłanką negatywną było prowadzenie postępowania upadłościowego, w którym nie zaspokojono wszystkich wierzycieli, a dłużnik po zakończeniu lub umorzeniu postępowania zobowiązań swych nie wykonał. Trzecia sytuacja miała miejsce, gdy prowadzono postępowanie o ogłoszenie upadłości konsumenckiej, jeżeli postępowanie to zostało umorzone $z$ innych przyczyn niż na wniosek wszystkich wierzycieli Ostatnią przesłanką była sytuacja, w której czynność prawna dłużnika została prawomocnie uznana za dokonaną z pokrzywdzeniem wierzycieli.

Przepis ten, wskazując dziesięcioletni okres, nawiązuje do ogólnego terminu przedawnienia roszczeń $z$ art. 118 Ustawy $z$ dnia 23 kwietnia 1964 r. - Kodeks cywilny (dalej: KC) ${ }^{17}$. Konstrukcja ta powodowała, że instytucja upadłości konsumenckiej była traktowana przez ustawodawcę jako przywilej o wyjątkowym charakterze ${ }^{18}$.

Wątpliwości interpretacyjne budziło sformułowanie dotyczące „innego postępowania, w którym umorzono całość lub część jego

regulacji, „Studia Iuridica Torunienisia”, t. V, 2009, s. 123-124, https://doi. org/10.12775/sit.2009.007, postanowienie SN z dnia 31 stycznia 2002 r., IV CKN 659/00, LEX nr 53150.

16 R. Adamus, A.J. Witosz, A. Witosz, op.cit., s. 67-68.

17 T. jedn.: Dz.U. z 2016 r. poz. 380 ze zm.

18 R. Adamus, A.J. Witosz, A. Witosz, op.cit., s. 66. 
zobowiązań albo w którym zawarto układ”. W przepisie tym chodziło chociażby o umorzenie zaległości podatkowych, wraz $z$ odsetkami za zwłokę, oraz opłaty prolongacyjnej, umorzenie należności z tytułu podatków i opłat stanowiących dochody jednostek samorządu terytorialnego, umorzenie nieuiszczonych kosztów sądowych oraz grzywien orzeczonych w postępowaniu cywilnym, umorzenie pożyczek i kredytów studenckich itp. Pomimo pojawienia się poglądu, że sąd mógł na tej podstawie oddalić wniosek o ogłoszenie upadłości w każdym przypadku umorzenia zobowiązań dłużnika w okresie 10 lat przed datą złożenia wniosku, nawet gdyby chodziło jedynie o grzywnę nałożoną w drodze mandatu karnego, należy uznać, że stanowisko to, jako zbyt daleko idące, pozbawiłoby instytucję upadłości konsumenckiej jakiegokolwiek praktycznego znaczenia ${ }^{19}$.

Przesłanka zawarta w przepisie art. $491^{3}$ ust. 2 pkt 4 pun, tj. oddalenie wniosku w sytuacji, gdy czynność prawna dłużnika została prawomocnie uznana za dokonaną z pokrzywdzeniem wierzycieli, była interpretowana poprzez pryzmat art. 527 i n. KC. Na skutek użycia identycznych sformułowań przez ustawodawcę uznawano, że brany pod uwagę tylko i wyłącznie może być w tym wypadku prawomocny wyrok wydany w oparciu o te przepisy ${ }^{20}$.

Sąd miał obowiązek oddalić wniosek o ogłoszenie upadłości także w sytuacjach wskazanych w art. 13 ust. 1 i 2 pun, tj. jeżeli majątek niewypłacalnego dłużnika nie wystarczał na zaspokojenie kosztów postępowania. Do fakultatywnych przesłanek należała także sytuacja, że majątek dłużnika jest obciążony hipoteką, zastawem, zastawem rejestrowym, zastawem skarbowym lub hipoteka morską w takim stopniu, że pozostały jego majątek nie wystarcza na zaspokojenie kosztów postępowania. Przepisy te nie zostały wyłączone w postępowaniu o ogłoszenie upadłości konsumenckiej, a co za tym idzie, już na etapie przyjmowania regulacji dostrzegano, że podstawą oddalenia będzie najczęściej brak majątku wystarczającego na zaspokojenie kosztów postępowania ${ }^{21}$. Praktyka potwierdziła

19 S. Gurgul, Prawo upadłościowe i naprawcze. Komentarz. Art. 4913. 2010, dostęp elektroniczny: System Informacji Prawnej Legalis (dostęp: 27.02.2017 r.).

20 R. Adamus, A.J. Witosz, A. Witosz, op.cit., s. 67.

21 S. Gurgul, op.cit. 
te obawy - liczba ogłoszonych upadłości konsumenckich w latach 2009-2014 nie przekroczyła 100, a trzeba pamiętać o tym, że nie w każdym przypadku ogłoszonej upadłości doszło do oddłużenia ${ }^{22}$.

Wprowadzenie po raz pierwszy do polskiego systemu prawnej instytucji upadłości konsumenckiej umożliwiło kompleksowe oddłużanie osób fizycznych. Kwestie dotyczące przesłanek formalnych, przede wszystkim konieczności pokrycia kosztów postępowania z majątku dłużnika, uniemożliwiły jednak wykorzystanie tego instrumentu prawnego na szerszą skalę.

\section{Przesłanki ogłoszenia upadłości po 31 grudnia $2014 \mathrm{r}$.}

Wspomniana nowelizacja $z$ dnia 29 sierpnia 2014 r. uzasadniana była koniecznością wprowadzenia na szerszą skalę dostępu osób fizycznych do oddłużenia i tzw. nowego startu. Konieczność wprowadzenia zmian najlepiej obrazował fakt, że na 2161 wniosków o ogłoszenie upadłości osób fizycznych nieprowadzących działalności gospodarczej w latach 2009-2012 wydano jedynie 60 postanowień o ogłoszeniu upadłości. Wśród przyczyn takiego stanu rzeczy wskazywano wąskie przesłanki ogłoszenia upadłości ograniczające tę możliwość do dłużników, których niewypłacalność powstała wskutek wyjątkowych i niezależnych od dłużnika okoliczności, barierę kosztów postępowania wynikającą ze stosowania w upadłości konsumenckiej art. 13 i 361 pun, co skutkowało oddaleniem wniosku o ogłoszenie upadłości albo umorzeniem postępowania, gdy dłużnik nie posiada majątku na pokrycie kosztów postępowania. Inną przyczyną były rygorystyczne przepisy przewidujące obligatoryjne umorzenie postępowania $\mathrm{w}$ razie wymienionych $\mathrm{w}$ ustawie uchybień dłużnika jego obowiązkom, nieuwzględniające istotności danego uchybienia ani stopnia pokrzywdzenia wierzycieli ${ }^{23}$.

22 P. Filipiak (red.), Upadłość konsumencka po dużej nowelizacji. Komentarz, Poznań 2015, s. 23.

${ }^{23}$ Uzasadnienie do projektu ustawy o zmianie ustawy - Prawo upadłościowe i naprawcze oraz niektórych innych ustaw z dnia 7 lutego 2014 r., druk nr 2265, 
Zmianom w obecnie obowiązującej wersji ustawy z dnia 28 lutego 2003 r. - Prawo upadłościowe ${ }^{24}$ (dalej: pu) podległy przesłanki ogłoszenia upadłości. Przede wszystkim w art. $491^{2}$ ust. 1 pu wyłączono stosowanie m.in. art. 13 i 361, co doprowadziło do znacznego zwiększenia dostępu do tej instytucji.

Pozytywną przesłanką ogłoszenia upadłości konsumenckiej pozostała niewypłacalność dłużnika, rozumiana jako utracenie zdolności do wykonywania swoich wymagalnych zobowiązań pieniężnych. Domniemywa się, że dłużnik spełnia tę przesłankę, jeśli opóźnienie w wykonaniu zobowiązań pieniężnych przekracza trzy miesiące (art. 11 ust. 1 i la pu). Istotną zmianą w stosunku do poprzedniego stanu prawnego było wprowadzenie regulacji zawarta w art. $491^{2}$ ust. 2, która dopuściła możliwość ogłoszenia upadłości konsumenckiej w przypadku, gdy dłużnik ma tylko jednego wierzyciela (wprowadzono tym samym istotną odmienność od postępowania o ogłoszenie upadłości przedsiębiorcy). Wniosek o ogłoszenie upadłości złożyć może wyłącznie dłużnik, z wyjątkiem sytuacji, gdy upadłość ma dotyczyć osób fizycznych, które były przedsiębiorcami i zostały wykreślone $z$ właściwego rejestru, a także osób fizycznych faktycznie prowadzących działalność gospodarczą, także wówczas, gdy nie dopełniły obowiązku zgłoszenia tej działalności we właściwym rejestrze. Wówczas na warunkach określonych w ustawie wniosek może złożyć także wierzyciel.

Wśród negatywnych przesłanek ustawodawca w obecnie obowiązującej regulacji wskazuje okoliczność, że dłużnik doprowadził do swojej niewypłacalności lub istotnie zwiększył jej stopień umyślnie lub wskutek rażącego niedbalstwa. Wcześniej w przypadku upadłości konsumenckiej konieczne było zaistnienie przesłanki, że niewypłacalność powstała na skutek wyjątkowych i niezależnych od dłużnika okoliczności. Ustawodawca, dostrzegając zbyt surowy kierunek wykładni tych przepisów, postanowił, że tylko rażące zawinienie, określone jako stan umyślności lub rażącego niedbal-

s. 15, http://orka.sejm.gov.pl/Druki7ka.nsf/0/DEFCFD38910FOB9DC1257CAE0030F5EC/\%24File/2265.pdf (dostęp: 27 lutego 2017 r.).

${ }^{24}$ Tekst jednolity: Dz.U. z 2015 r. Poz. 233 z zm. 
stwa, skutkować będzie oddaleniem wniosku o ogłoszenie upadłości. Doprecyzowano jednocześnie, że nie chodzi tylko o czynności prowadzące do doprowadzenia do niewypłacalności, ale również istotnego zwiększenia jej stopnia ${ }^{25}$.

W znowelizowanej ustawie utrzymano zasadę, że oddłużenie jest przywilejem, którego nie można nadużywać za pomocą postępowania upadłościowego. Sąd na tej podstawie obligatoryjnie oddala wniosek o ogłoszenie upadłości w sytuacjach, gdy w ciągu 10 lat przed dniem zgłoszenia wniosku w stosunku do dłużnika prowadzono postępowanie o ogłoszenie upadłości konsumenckiej, jeżeli postępowanie to zostało umorzone $z$ innych przyczyn niż na wniosek dłużnika, ustalony dla dłużnika plan spłaty został uchylony na skutek niewykonywania przez upadłego obowiązków w nim określonych (art. $491^{20} \mathrm{pu}$ ), dłużnik, mając taki obowiązek, wbrew przepisom ustawy nie zgłosił w terminie wniosku o ogłoszenie upadłości, czynność prawna dłużnika została prawomocnie uznana za dokonaną z pokrzywdzeniem wierzycieli. Ustawodawca jednak dokonał przełamania tego dotychczas bezwzględnego zakazu i umożliwił ogłoszenie kolejnej upadłości, jeśli przeprowadzenie postępowania jest uzasadnione względami słuszności lub względami humanitarnymi.

Ponadto sąd zgodnie $\mathrm{z}$ art. $491^{4}$ ust. 3 pu oddala wniosek o ogłoszenie upadłości, jeżeli w okresie 10 lat przed dniem zgłoszenia wniosku w stosunku do dłużnika prowadzono postępowanie upadłościowe, w którym umorzono całość lub część jego zobowiązań, chyba że do niewypłacalności dłużnika lub zwiększenia jej stopnia doszło pomimo dochowania przez dłużnika należytej staranności lub przeprowadzenie postępowania jest uzasadnione względami słuszności lub względami humanitarnymi. Aby zapobiec składaniu nierzetelnych lub niezgodnych $z$ prawdą wniosków, wprowadzono regulację, na podstawie której sąd oddala wniosek o ogłoszenie upadłości, jeżeli dane podane przez dłużnika we wniosku są niezgodne z prawdą lub niezupełne, chyba że niezgodność lub niezupełność nie są istotne lub przeprowadzenie postępowania jest uzasadnione względami słuszności lub względami humanitarnymi.

25 P. Filipiak (red.), Upadłość konsumencka, s. 28. 
Wspomniane wyłączenie art. 13 pu w postępowaniu dotyczącym upadłości konsumenckiej oznacza, że w ramach upadłości konsumenckiej nie występuje instytucja tzw. ubóstwa masy upadłości. Sąd obecnie nie może oddalić wniosku lub umorzyć toczącego się postępowania $z$ uwagi na fakt, że majątek dłużnika (lub upadłego) nie wystarczy na zaspokojenie kosztów postępowania ${ }^{26}$.

Dla doprecyzowania stanu prawnego i usunięcia wątpliwości na gruncie nowelizacji z dnia 29 sierpnia 2014 r. dokonany zmiany art. 6 ust. 5, wskazującego, że nie można ogłosić „ogólnej” (dotyczącej przedsiębiorców) upadłości osób fizycznych prowadzących gospodarstwo rolne, które nie prowadzą innej działalności gospodarczej lub zawodowej. Zgodnie $z$ treścią art. $491^{1}$ takie osoby będą objęte wyłącznie możliwością ogłoszenia upadłości konsumenckiej27.

Reforma w zakresie przesłanek ogłoszenia upadłości doprowadziła do znacznego skrócenia, uproszczenia oraz obniżenia kosztów postępowania w przedmiocie ogłoszenia upadłości. Przed jej dokonaniem to właśnie zdolność upadłego do pokrycia kosztów postępowania była główną przeszkodą do ogłoszenia upadłości. Obecnie jeśli pokrycie kosztów nie będzie możliwe $z$ majątku dłużnika (zarówno istniejącego w dniu ogłoszenia upadłości, jak i pozyskanego w trakcie postępowania), ustawodawca przewidział, że koszty postępowania w takich sytuacjach tymczasowo pokrywa Skarb Państwa. Jeśli po ogłoszeniu upadłości okaże się, iż upadły nie będzie zdolny do dokonania jakichkolwiek spłat w ramach planu spłaty wierzycieli, w tym Skarbu Państwa, sąd ostatecznie obciąży Skarb Państwa tymczasowo poniesionymi kosztami ${ }^{28}$.

Uchylenie bezwzględnego charakteru przesłanek negatywnych względami słuszności oraz względami humanitarnymi doczekało się licznych interpretacji w orzecznictwie. I tak przykładowo Sąd Okręgowy w Bydgoszczy w postanowieniu z dnia 18 czerwca 2015 r. $^{29}$ wskazał, że chodzi tutaj o sytuacje, „gdy niewypłacalność była

${ }^{26}$ Ibidem, s. 29-30.

27 Uzasadnienie do projektu ustawy, s. 17.

28 P. Filipiak (red.), Upadłość konsumencka, s. 90.

29 Postanowienie SO w Bydgoszczy z dnia 18 czerwca 2015 r., VIII Gz 69/15 http://orzeczenia.bydgoszcz.so.gov.pl/content/\$N/151005000004027_VIII_ Gz_000069_2015_Uz_2015-06-18_001 (dostęp: 27.02.2016 r.). 
skutkiem okoliczności o charakterze obiektywnym (np. kalectwa, choroby, niezawinionej utraty źródeł zarobkowania i obiektywnej niemożność powrotu do poprzedniego stanu), a także gdy przemawiają za tym silne argumenty o charakterze społecznym, słusznościowym czy humanitarnym - wynikające przede wszystkim Z aktualnej sytuacji konsumenta”.

Nowelizacja Prawa upadłościowego w zakresie upadłości konsumenckiej doprowadziła do minimalizacji roli bezwzględnych przesłanek, a w niemal każdym przypadku sąd ma możliwość ogłoszenia upadłości osoby fizycznej nieprowadzącej działalności gospodarczej z uwagi na względy słuszności i humanitarne. Prowadzi to do większej możliwości rozważania przez sądy indywidualnych okoliczności każdej sprawy. Wyjątkowość sytuacji dłużnika, która w latach 2009-2014 była jedną z podstawowych, koniecznych przesłanek ogłoszenia upadłości konsumenckiej, obecnie umożliwia ogłoszenie upadłości nawet w sytuacjach, w których sąd co do zasady jest obowiązany do oddalenia wniosku.

\section{Podsumowanie}

Interes wierzycieli, który przemawia za możliwością spłaty przez dłużników zadłużenia w jak największym stopniu, a także zapobieganie poczucia bezkarności nierzetelnych dłużników przemawiają za ograniczeniem dostępu do instytucji ogłoszenia upadłości do sytuacji wyjątkowych. Względy humanitarne, a także możliwość przywrócenia osób nadmiernie zadłużonych dla rynku pracy, umożliwienia im normalnego funkcjonowania w społeczeństwie i redukcji często nieświadomie zawartych zobowiązań przemawiają z kolei za umożliwieniem korzystania $z$ tej instytucji jak najszerszej liczbie osób fizycznych nieprowadzących działalności gospodarczej.

Mechanizmem umożliwiającym ustawową ingerencję w określenie dostępu do tej instytucji jest odpowiednie sformułowanie przesłanek pozytywnych i negatywnych ogłoszenia upadłości. W systemach praw europejskich podkreśla się wyjątkowość tej instytucji, ograniczając możliwość składania kolejnych wniosków w krótkich odstępach czasu, a także piętnuje się działanie w złej wierze, ze 
świadomością pokrzywdzenia właścicieli. W części państw, zwłaszcza tych, które przewidują obowiązkową procedurę przedsądową przed rozpoczęciem etapu sądowego w sprawie ogłoszenia upadłości konsumenckiej, dłużnik musi również udowodnić niepowodzenie negocjacji prowadzonych $\mathrm{z}$ wierzycielami w zakresie polubownego ustalenia sposobu restrukturyzacji zobowiązań.

$Z$ tego punktu widzenia niebywale rygorystyczna, praktycznie zamykająca drogę do skorzystania $z$ tej instytucji polska regulacja prawna obowiązująca w latach 2009-2014 nie znajdywała żadnego uzasadnienia, czy to w interesie wierzycieli, czy też dłużników. Głównym kryterium uniemożliwiającym uwzględnienie wniosku o ogłoszenie upadłości okazało się kryterium formalne, ekonomiczne, a mianowicie konieczność posiadania określonego majątku, który wystarczyłby na pokrycie kosztów prowadzonego postępowania upadłościowego. O ile takie rozwiązanie może działać prewencyjnie na przedsiębiorców, którym powinno zależeć, aby na jak najwcześniejszym etapie niewypłacalności złożyć wniosek o ogłoszenie upadłości, aby zaspokoić wierzycieli w jak największym stopniu, o tyle nie miało ono żadnego racjonalnego uzasadnienia w stosunku do konsumentów.

Zmiany, jakie zostały dokonane od 2014 r., należy oceniać jednoznacznie pozytywnie. Zniesienie bezwzględnego charakteru części przesłanek negatywnych, a także umożliwienie prowadzenia postępowania przy braku majątku wystarczającego na zaspokojenie jego kosztów doprowadziły do znacznego zwiększenia roli tej instytucji w praktyce.

Formułując postulaty de lege ferenda, należałoby zastanowić się, czy $z$ uwagi na negatywne doświadczenia dotyczące stosowania części przepisów postępowania upadłościowego dotyczącego przedsiębiorców, takie jak wymóg wielości wierzycieli oraz konieczność pokrycia kosztów postępowania $z$ majątku upadłego, nie przemawiałyby raczej za kompleksową regulacją upadłości konsumenckiej w ramach odrębnej ustawy. Należałoby również rozważyć odformalizowanie postępowania w zakresie prawidłowego wskazania wszystkich składników majątku przez dłużnika, gdyż obecnie nawet nieświadomie niepełne wskazanie przez dłużnika posiadanego majątku może skutkować oddaleniem wniosku. Rozwiązaniem, którego 
wprowadzenie można by rozważyć, jest ustalenie całego majątku jeszcze przed ogłoszeniem upadłości przy pomocy syndyka, który i tak dokonuje ustaleń w tym zakresie po ogłoszeniu upadłości.

\section{STRESZCZENIE}

Pozytywne i negatywne przesłanki ogłoszenia upadłości konsumenckiej

Konsument, który nie jest w stanie spłacać swoich zobowiązań, może od 2009 r., zgodnie z polskim prawem, złożyć wniosek o ogłoszenie upadłości. Jednakże postępowanie to było bardzo restrykcyjne, a jego dostępność ograniczona. Ustawa pozwalała osobom fizycznym nieprowadzącym działalności gospodarczej złożyć wniosek o ogłoszenie upadłości konsumenckiej tylko w wyjątkowych okolicznościach pozostających poza ich kontrolą, takimi jak choroba czy utrata zatrudnienia. W artykule zestawiono przesłanki ogłoszenia upadłości konsumenckiej w Polsce i innych krajach Unii Europejskiej. Autor prezentuje również różnice pomiędzy sformułowaniem przesłanek przed nowelizacją polskiego prawa upadłościowego w 2014 r. oraz po niej.

Słowa kluczowe: upadłość konsumencka; upadłość osób fizycznych; przesłanki ogłoszenia upadłości konsumenckiej

\section{SUMMARY}

Positive and negative conditions for declaring consumer bankruptcy

The consumer who is unable to pay his or her obligation can after year 2009 under Polish law file for personal bankruptcy. However, the procedure was very strict and was not widely available. The statute allows individuals to file for personal bankruptcy only in extraordinary circumstances that are beyond their control, such as unexpected illness or loss of employment. Conditions for declaring consumer bankruptcy in Poland and other EU countries are compared in the article. The Author also presents differences between conditions before and after coming into force of Polish Bankruptcy Act amendment in year 2014. 
Keywords: consumer bankruptcy; personal bankruptcy; conditions for declaring consumer bankruptcy

\section{BIBLIOGRAFIA}

Adamus R., Witosz A.J., Witosz A., Upadłość konsumencka. Komentarz praktyczny, Warszawa 2009.

Filipiak P. (red.), Upadłość konsumencka po dużej nowelizacji. Komentarz, Poznań 2015.

Gurgul S., Prawo upadłościowe i naprawcze. Komentarz. Art. 49133. 2010, dostęp elektroniczny: System Informacji Prawnej Legalis (dostęp: 27.02. 2017 r.).

Kabza E., Wybrane problemy upadłości konsumenckiej $w$ świetle nowej regulacji, „Studia Iuridica Torunienisia”, t. V, 2009, s. 121-139., https:// doi.org/10.12775/sit.2009.007.

Reifner U., Kiesilainen J., Huls N., Springeneer H., Consumer Overindebtness and Consumer Law in European Union, Final Report, http://www. ecri.eu/new/system/files/26+consumer_overindebtedness_consumer_ law_eu.pdf (dostęp: 26.02.2017 r.).

Szpringer W., Upadłość konsumencka. Inspiracje z rozwiązań światowych oraz rekomendacje dla Polski, Warszawa 2006.

Szymańska A., Upadłość konsumencka $w$ Polsce na tle doświadczeń innych krajów Unii Europejskiej, Warszawa 2014. 